CZASOPISMO INŻYNIERII LĄDOWEJ, ŚRODOWISKA I ARCHITEKTURY JOURNAL OF CIVIL ENGINEERING, ENVIRONMENT AND ARCHITECTURE

JCEEA, t. XXX, z. 60 (1/13), styczeń-marzec 2013, s. 49-58

\author{
Galina KALDA ${ }^{1}$ \\ Igor KOVTUN ${ }^{2}$ \\ Katerina SOKOLAN ${ }^{3}$
}

\title{
SOLAR ENERGY AND POSSIBILITIES OF ITS USAGE
}

\begin{abstract}
This paper represents ways to produce electric power and heat by means of solar radiation. There are described advantages and disadvantages of using solar energy in modern conditions. There are shown examples of using Sun energy in variety of manufacturing branches and transport.

Solar energy is assumed a solar radiation which is used to produce some kind of power. Solar power uses renewable source of energy and can become one which would be, in perspective, ecologically clean so as to not produce hazardous wastes. Now solar power is being widely used when scarce of other sources of energy added by plenitude of solar radiation is economically reasonable.

Theoretically the advantage of solar energy is in its total safety for environment (however manufacturing photo-cells uses harmful substances). There's potential risk that total implementing of solar power can change albedo of the Earth surface and bring to changes in its climate. But in the modern level of using this power it's highly unlikely.

The problem of having large spaces of the ground under solar installations is solved by using solar aerostat power stations, applicable to land, sea or air bases. Solar energy flow that reaches the Earth surface strongly depends on latitude and climate. For different places the average annual amount of sunny days can vary significantly.

The problem that power of solar power station depends on time of the day and weather is solved by solar aerostat power stations.

The next problem is the high price set on solar photocells. This disadvantage can be probably eliminated with developing technology. Today prices for photocells lower at the average by $4 \%$ annually.
\end{abstract}

Keywords: solar radiation, solar energy, using energy

\footnotetext{
${ }^{1}$ Autor do korespondencji: Galina Kalda, Rzeszow University of Technology, 6 Powstancow Warszawy Avenue, 35-959 Rzeszow, tel. +48 17 8651068, kaldagal@ prz.edu.pl.

2 Igor Kovtun, Khmelnytsky National University, 11 Instytutska Street, Khmelnytsky, 29016 Ukraine, tel. +38 0682023812, ikov@ tup.km.ua.

${ }^{3}$ Katerina Sokolan, Khmelnytsky National University, 11 Instytutska Street, Khmelnytsky, 29016 Ukraine, tel. +38 0681732840, sokolan@ @up.km.ua.
} 


\section{Introduction}

Solar energy is assumed a solar radiation which is used to produce some kind of power. Solar power uses renewable source of energy and can become one which would be, in perspective, ecologically clean so as to not produce hazardous wastes.

Now solar power is being widely used when scarce of other sources of energy added by plenitude of solar radiation is economically reasonable. Some individuals and organizations are also using it due to their idea to focus on exploring ecological harmless dispersed solar energy.

\section{The ways to generate electricity and heat by solar radiation Generating electricity by photo-cell}

Let's consider the ways to generate electricity and heat by variety of photocells, which are used now in solar power stations.

Helio-thermal power industry uses heating surface, by absorbing solar rays, and further distributing and using produced heat (focusing solar radiation on vessel with water to use hot water for heating or steam power generators).

Solar sail can transform solar rays into kinetic power in vacuum.

Thermal air power stations are those transforming solar power into power of airflow led to turbo-generator.

Helio-power stations are solar installations using high-concentration solar radiation as a power to activate thermal and other machines (vapor, gas-turbine, thermal-electrical).

Solar aerostat power stations generate water steam inside a balloon of aerostat by solar radiation heating aerostat's surface covered with selectiveabsorbing coat. The advantage of such power stations is that vapor resource in balloon is enough to keep power station working in conditions of low illumination and unfavorable weather.

Solar radiation stream incident to $1 \mathrm{~m}^{2}$ surface perpendicular to this radiation at the distance of one astronomic unit from Sun center (out of Earth atmosphere) equals $1367 \mathrm{Wt} / \mathrm{m}^{2}$ (solar constant). The absorbing of Earth atmosphere makes it equal $1020 \mathrm{Wt} / \mathrm{m}^{2}$ at the sea level. However it's important to consider the fact that daily average rate of solar radiation is at least three times lower (because of changing day and night, and angle between Sun and horizon). In winter in the middle latitude this value is two times lower. This quantity of energy gained from one unit of illuminated area determines perspectives of solar power.

Photo-electric cells are semi-conductors directly transforming solar power into electricity (photo-cells). A set of assembled cells is called solar battery.

Solar collectors are solar heated low-temperature installations. 
Fig. 1. Generating energy by photo-cells

Rys. 1. Wytwarzanie energii przez fotokomórki

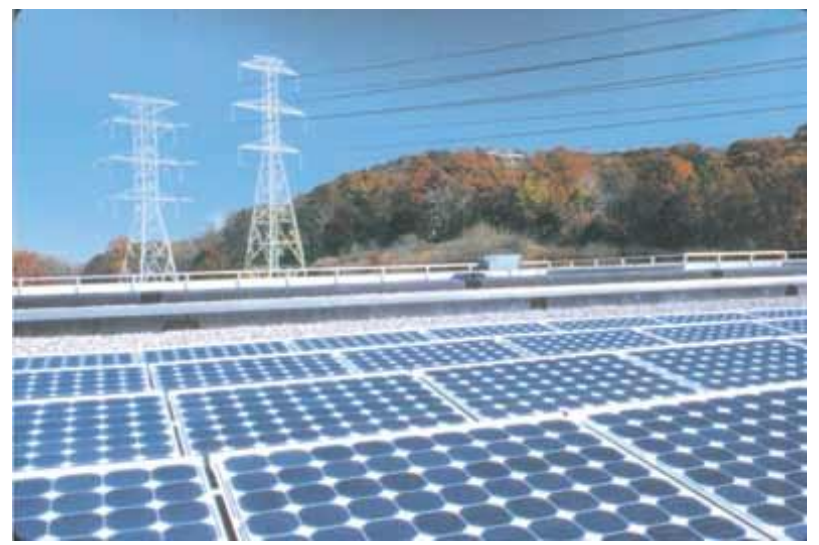

Fig. 2. Laundry supplied by solar power

Rys. 2. Pralnia zaopatrywana przez energię słoneczną

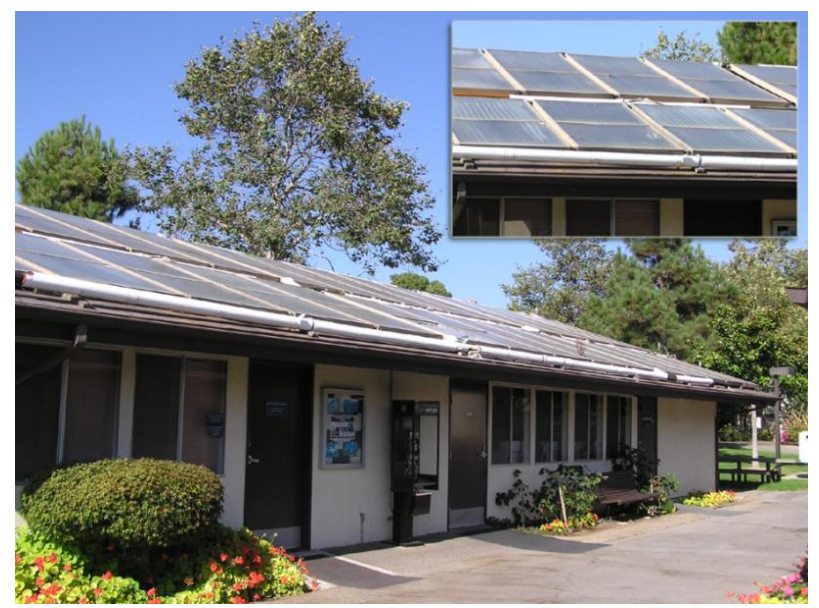

Fig. 3. Solar radiation map

Rys. 3. Mapa promieniowania słonecznego
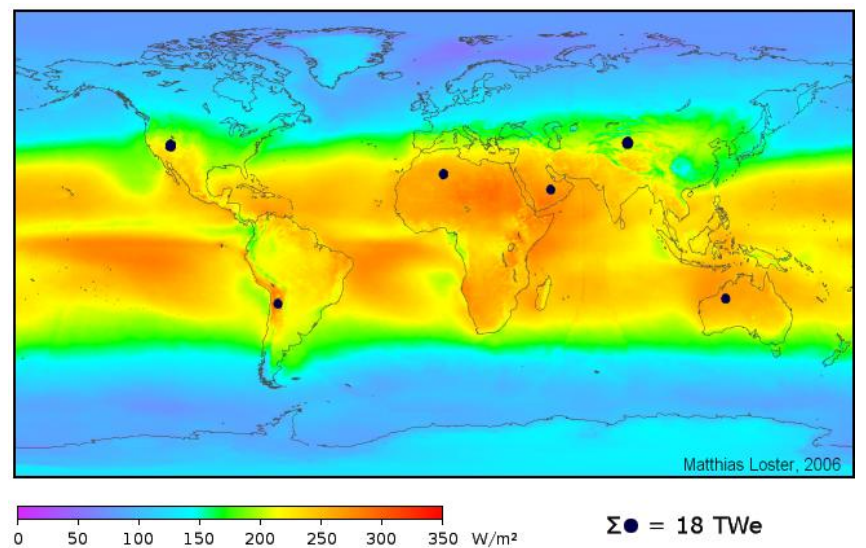
Organic batteries are units transforming solar rays into electricity by genetically modified cells, printed on thin plastic with conductor.

Figure 1 represents example of photo-cell generating energy. Figure 2 demonstrates effective usage of photo-cells supplying laundry $[1,2]$. Regions of our planet, which are richly provided with solar radiation during the whole year are shown in Fig. 3 [3].

\section{Advantages of solar power}

\section{Availability and inexhaustibility of the source}

Theoretically the advantage of solar energy is in its total safety for environment (however manufacturing photo-cells uses harmful substances). There's potential risk that total implementing of solar power can change albedo of the Earth surface and bring to changes in its climate. But in the modern level of using this power it's highly unlikely $[4,5]$. Figure 4 shows solar batteries on the roof of Science Academy of Russia supplying illumination and heating.

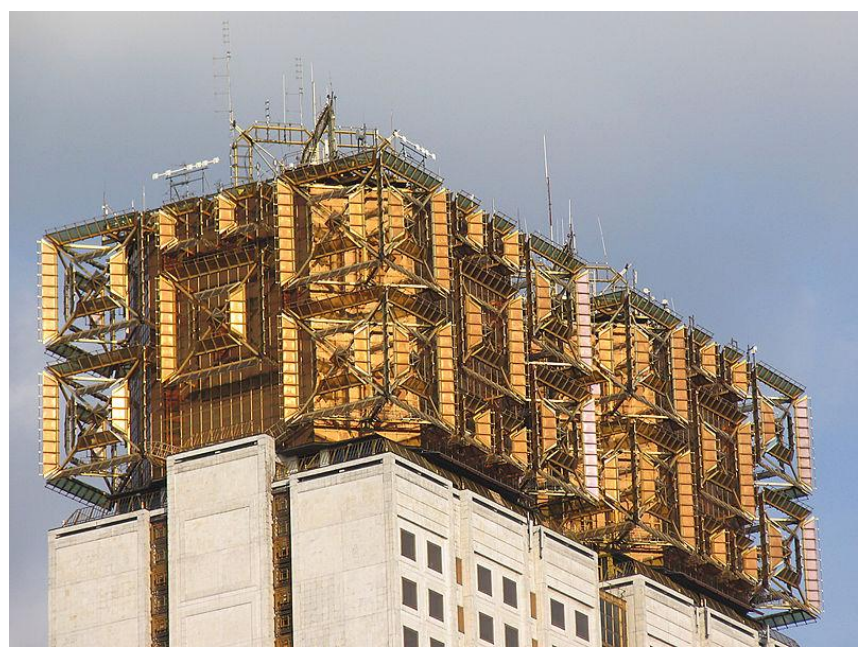

Fig. 4. Solar batteries on the roof of Science Academy of Russia

Rys. 4. Baterie słoneczne na dachu Akademii Nauk Rosji

\section{Disadvantages of solar power}

\subsection{Fundamental problems}

Relatively low value of the solar constant makes solar industry occupy large areas for power stations (for example, $1 \mathrm{GWt}$ power station may need a few square kilometers area). However this disadvantage is not that big, for example hydro-power industry takes away much larger piece of the ground. Besides, 
photo-cells are installed at the height of 1.8-2.5 m, what allows using the ground under it for agriculture or a stock walk.

The problem of having large spaces of the ground under solar installations is solved by using solar aerostat power stations, applicable to land, sea or air bases. Solar energy flow that reaches the Earth surface strongly depends on latitude and climate. For different places the average annual amount of sunny days can vary significantly.

\subsection{Technical problems}

Solar power station works neither in night hours nor effectively in morning and evening hours. At the same time the pick consumption of electricity occurs in evening. Besides, the power of the station can rapidly and unexpectedly vary because of weather changes. To overcome these disadvantages it's needed either to use effective electric accumulators (this problem hasn't been solved by now) or to build hydro-accumulative stations, which occupy also large territory, or to use hydrogen power concept, which is still far from economic benefits.

The problem that power of solar power station depends on time of the day and weather is solved by solar aerostat power stations.

The next problem is the high price set on solar photocells. This disadvantage can be probably eliminated with developing technology. Today prices for photocells lower at the average by $4 \%$ annually.

Another disadvantage of solar elements is their insufficient efficiency factor. The surface of photo-panels should be regularly cleaned from dust and other contamination, but having their area measured in square kilometers can complicate it.

Photo-cell efficiency reduces at its warming, what entails necessity to install cooling systems, usually water ones. After 30 years exploring effectiveness of photo-cells will decrease.

\subsection{Ecological problems}

Although this type of energy is ecologically pure, the photo-cells themselves contain harmful substances, for example, lead, cadmium, gallium, arsenic etc., and their manufacturing uses lots of another dangerous substances. The lifetime of modern photo-cells is limited (30-50 years) and their global using will pose the complicated problem of their utilizing, which also doesn't have a solution acceptable for ecology.

Recently it's been developing manufacturing of thin-film photo-cells whose structure contains about $1 \%$ silicium. Due to low contents of silicium thin-film photo-cells are cheaper but have lower efficiency so far. For example in 2010 "Shell" Company made a decision to focus on manufacturing thin-film elements and sold its business on manufacturing silicium photo-cells. 


\section{Using solar power in chemical industry}

Solar energy can be applied to many chemical processes. For example, Israel Weizmann Institute of Science in 2010 tested new technology to produce non-oxidated zinc in solar tower. Zinc oxide in presence of charcoal was heated to $1200 \mathrm{deg} C$ temperature on the top of solar tower. The process results in pure zinc. Further zinc can be sealed and transported to plants generating electric power. Having been delivered to the plant zinc is settled in the water, and chemical reaction generates hydrogen and zinc oxide. Zink oxide can be recycled to get pure zinc in solar tower. Technology has passed testing in solar tower of Canadian Institute for the Energies and Applied Research.

Swiss Company Clean Hydrogen Producers (CHP) has developed technology for manufacturing hydrogen from water by means of parabolic solar concentrators. The area of mirrors in installation makes $93 \mathrm{~m}^{2}$. In the focus of concentrator temperature reaches $2200 \mathrm{deg} \mathrm{C}$. Water gets to separate into hydrogen and oxygen at more than $1700 \mathrm{deg} \mathrm{C}$ temperature. For the light time of the day 6.5 hours $\left(6.5 \mathrm{kWt} \cdot \mathrm{hr} / \mathrm{m}^{2}\right)$ CHP installation can separate 94.9 litters of water into hydrogen and oxygen. This will produce $3800 \mathrm{~kg}$ of hydrogen annually (about $10.4 \mathrm{~kg}$ per day). fuel.

Hydrogen can be used for manufacturing electric power or as a transport

\section{Solar transport}

Photo-cells can be installed on various means of transport: boats, electrocars and hybrid-cars, planes, airships etc. (Figs. 5 and 6). Photo-cells generate electricity, which can be used as on-board supply or to power electric engine of the transport means.

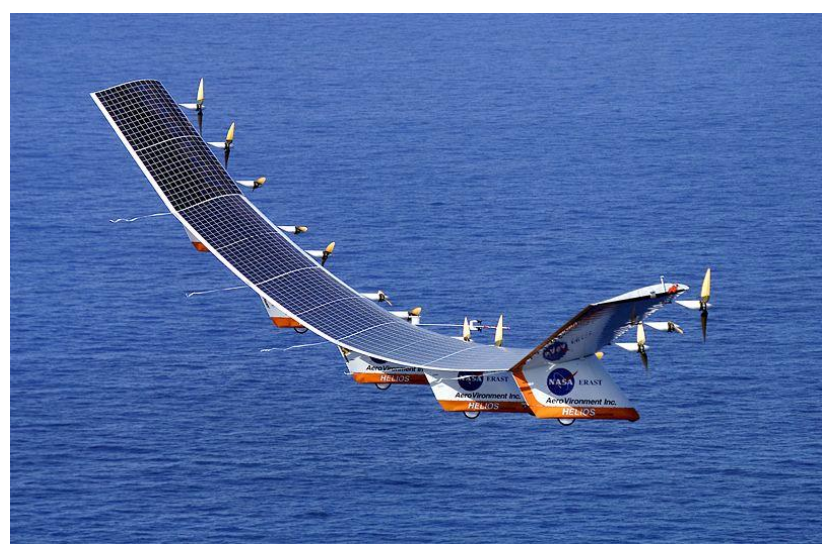

Fig. 5. Unmanned plane Helios with photo-cells on wings

Rys. 5. Bezzałogowy samolot Helios z fotokomórkami na skrzydłach 


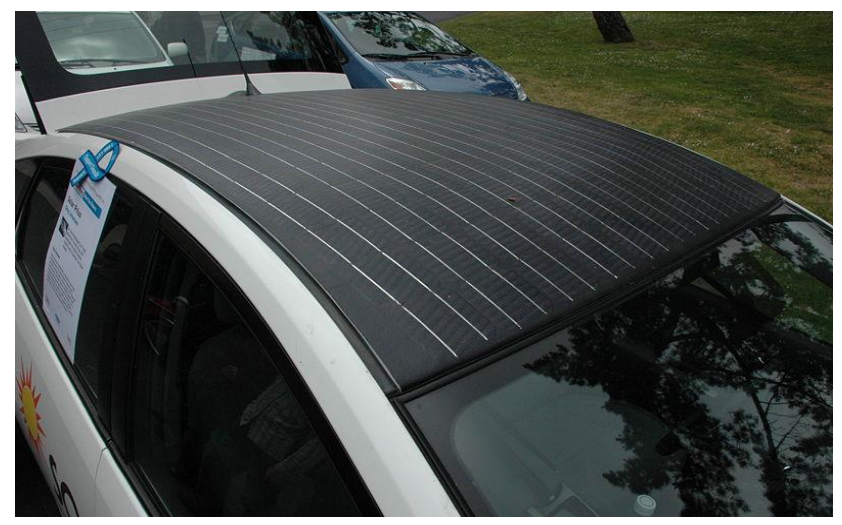

Fig. 6. Photo-cells on the roof of car Prius, 2008

Rys. 6. Fotokomórki na dachu samochodu Prius, 2008

In Italy and Japan photo-cells are installed on the train roof. They supply with electricity conditioning, lighting and emergency systems.

Solatec LLC Company trades thin-film photo-cells to be installed on the roof of hybrid-car Toyota Prius. Thin-film photo-cells have thickness of $0.6 \mathrm{~mm}$ what has no effect on car aero-dynamics. Photo-cells are purposed to charge car accumulator what allows $10 \%$ increasing of its mileage.

\section{Using solar batteries}

Solar batteries are widely used in tropic and sub-tropic regions with high amount of sunny days (Fig. 3). They are especially popular in Mediterranean countries where they are set on the roofs of living buildings for heating water and generating electricity. In perspective they will be used to charge electro-cars (Fig. 6) [6,7].

Solar battery is a type of alternative energy generators, transforming solar electromagnetic radiation into electricity. It's in the research objective of heliopower industry. Manufacturing solar batteries is developing very intensively. One of the types of solar batteries is shown in Fig. 7.

Solar radiation flow incident to one square meter not taking into consideration its loss in atmosphere makes 1350 Watts. At the same time partial power of solar radiation in Europe in cloudy weather even during the day can be less than $100 \mathrm{Wt} / \mathrm{m}^{2}$. By means of mostly used solar batteries this energy can be transformed into electricity with 9-24\% efficiency. In this case the price for battery makes 1-3 dollars at one kilo Watt of nominal power. At industrial generating electricity by photo-cells the price for one kilo Watt will make 0.25 dollars. By 2013 their prime price will go down to 0.15 dollars. Figure 8 shows one of the industrial types of solar-wind installations. 


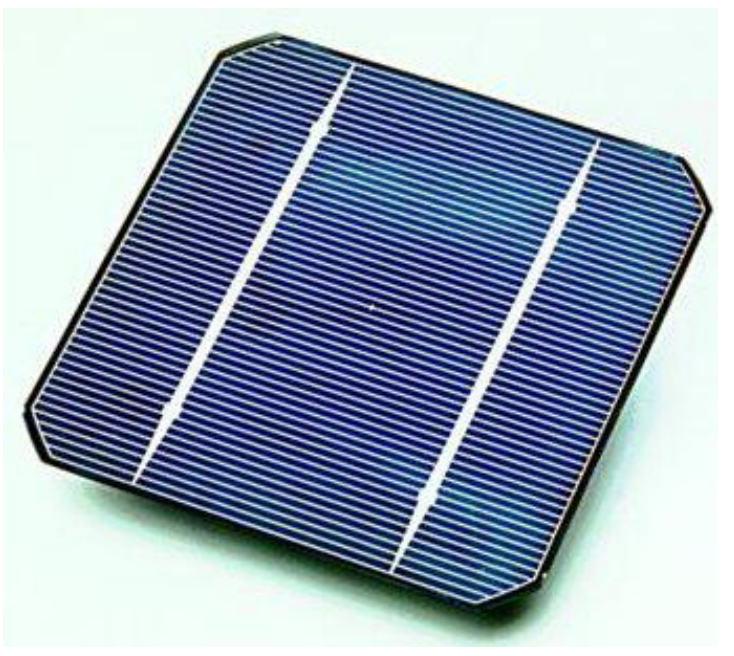

Fig. 7. Solar battery

Rys. 7. Bateria słoneczna

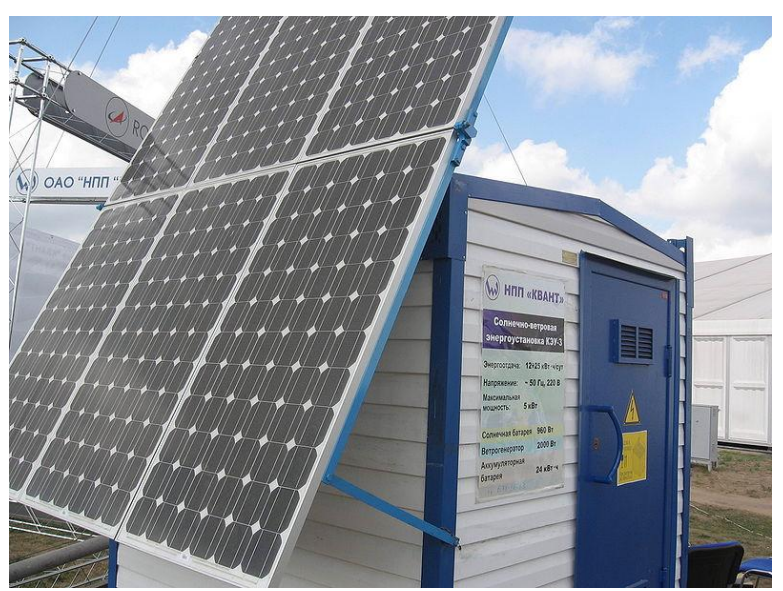

Fig. 8. Solar-wind installation

Rys. 8. Instalacja Solar-wind

Some laboratories have created solar elements with $44 \%$ efficiency factor. Russian scientists (c. Dubna) have created elements with 54\% efficiency factor, but these highly effective panels can't be widely used because of their high price [4].

Solar battery is one of the main ways to get electric power on space ships: they have long lifetime with no spending any material and at the same time are ecologically clean (unlike nuclear and radio-isotope reactors).

However while the flights remote from sun (behind Mars orbit) their usage becomes complicated because the sun energy flow is inversely proportional to square distance from Sun. As for flying to Venus and Mercury, on contrary, the power of solar batteries significantly rises (in Venus area - by two times, in Mercury area - by six times). 


\section{Conclusion}

Thus, possibilities of using solar energy in various branches aimed at reducing price for energy resources and improving ecology on our planet are quite high and insufficiently used by many states today. Reaching for usage of solar energy is the actual goal of mankind now, what will give a chance to have chip electricity and heat on one hand and to improve ecology on the planet on the other hand.

\section{References}

1. Kalda G., Pietrucha-Urbanik K., Studziński A.: Możliwości zastosowania powietrznych kolektorów słonecznych w gospodarce polskiej. Oficyna Wydawnicza Politechniki Rzeszowskiej. Zeszyty Naukowe Politechniki Rzeszowskiej, seria: Budownictwo i Inżynieria Środowiska, 2/2012, 59, 365-372.

2. Kalda G., Pietrucha-Urbanik K., Studziński A.: Możliwości zastosowania ogniw fotowoltaicznych w budownictwie. Oficyna Wydawnicza Politechniki Rzeszowskiej, Zeszyty Naukowe Politechniki Rzeszowskiej, seria: Budownictwo i Inżynieria Środowiska, 2/2012, 59, 361-364.

3. Romanov J.: Solar market. Delovoj Vestnik, 09(172), 2008.

4. Krylov O.V.: Limited resources as the cause of forthcoming crisis. Vestnic of Russian Science Academy, 70, 2, 2000, 136-146.

5. Kalda G., Smorag A.: Budowa i obliczanie powierzchni kolektorów słonecznych. Oficyna Wydawnicza Politechniki Rzeszowskiej, Zeszyty Naukowe Politechniki Rzeszowskiej, seria: Budownictwo i Inżynieria środowiska, 283, 59(/1/12/I), 103-115.

6. Kalda G., Smorag A.: Stan obecny sektora energetyki słonecznej w Polsce i prognoza jej wykorzystania w przyszłości. Oficyna Wydawnicza Politechniki Rzeszowskiej, Zeszyty Naukowe Politechniki Rzeszowskiej, seria: Budownictwo i Inżynieria Środowiska, 283, 4/2012, 59, 59-68.

7. Kalda G., Paterek R.: Perspektywy wykorzystania energii słonecznej w Polsce. Oficyna Wydawnicza Politechniki Rzeszowskiej, Zeszyty Naukowe Politechniki Rzeszowskiej, seria: Budownictwo i Inżynieria Środowiska, 2/2011, 58, 89-95.

\section{ENERGIA SŁONECZNA I MOŻLIWOŚCI JEJ ZASTOSOWANIA}

\section{Streszczenie}

Artykuł reprezentuje zasoby otrzymania energii elektrycznej i ciepła w wyniku promieniowania słonecznego. W pracy opisano zalety i wady zastosowania energetyki słonecznej, a także przytoczono przykłady wykorzystania energii Słońca w różnych rodzajach przemysłu i transportu. Energia słoneczna jest przyjmowana $\mathrm{z}$ promieniowania słonecznego, które jest wykorzystywane do produkcji pewnej ilości energii. Energia słoneczna używa odnawialne źródło energii i może stać się jedną z ekologicznie czystych, nieprodukującą niebezpiecznych ubytków. Obecnie energia słoneczna jest coraz częściej używana, ponieważ jest ekonomicznie opłacalna.

Ogólnie, energia słoneczna jest bezpieczna dla środowiska, mimo szkodliwych substancji w produkcji ogniw, które uzupełniając energię słoneczną, mogą zmieniać powierzchnię Ziemi 
i doprowadzać do zmian klimatu. Jednak przy obecnym wykorzystaniu energii Słońca jest to mało prawdopodobne.

Problem udostepnienia wielkich powierzchni na ziemi pod instalacje solarne jest rozwiazywany przez zastosowanie stacji słonecznych zlokalizowanych na lądzie, morzu lub nad powierzchnią ziemi. Ilość energii słonecznej docierającej do powierzchni Ziemi zależy od szerokości i klimatu. Dla różnych miejsc przeciętna roczna suma dni słonecznych może znacząco się zmieniać. Moc energii słonecznej zależy od pory dnia i pogody. Znaczącym utrudnieniem jest wysoka cena instalacji ogniw, które prawdopodobnie zostanie wyeliminowane wraz z rozwojem technologicznym. Dzisiaj cena ogniw obniża się, osiągając rocznie $4 \%$ spadek.

Słowa kluczowe: promieniowanie słoneczne, energetyka słoneczna, wykorzystanie energii

DOI: $10.7862 / \mathrm{rb} .2013 .4$

Przestano do redakcji w styczniu $2013 \mathrm{r}$.

Przyjęto do druku w czerwcu 2013 r. 